\title{
Implementation of Fraud Risk Assessment on Domestic Revenue Cycle of PT X (Case Study of Tiles Company)
}

\author{
Daisy Wijaya Kusuma \\ Departement of Accounting \\ Faculty Economics and Business, Universitas Indoneisa \\ Depok, Indonesia daisywijayakusuma@gmail.com
}

\begin{abstract}
This study discusses design and implementation process of fraud risk assessment on domestic revenue cycle of PT X, applying COSO framework; Fraud Risk Management Guide 2017. This study uses qualitative approach with case study method. Interview, observation, survey, and documentation are used to collect the data. Content analysis method is used to analyze primary and secondary data. This study observes PT $X$ as single unit analysis. PT $X$ is a leading tiles company which has been operating for 28 years in Indonesia. In 2017 PT $X$ just began a whistleblowing mechanism and in last six months the reports were related to fraud in goods delivery process. The purposes of this study are to implement fraud risk assessment on domestic revenue cycle, to design anti-fraud strategies for management of PT $X$, and to create audit program to test effectiveness of control related to the identified fraud risks. The main risky area on domestic revenue cycle of PT $X$ are Sales Administration, Warehouse, and Finance Accounts Receivable. The identified risks on domestic revenue cycle are mostly corruption and assets misappropriation. Most identified risks fell on high risk area.
\end{abstract}

Keywords: fraud, fraud risk assessment, control

\section{INTRODUCTION}

Many entities treat fraud as residual operational risk, in fact fraud risk can be identified and managed. Albrecht [1] stated that organization is able to proactively eliminate fraud opportunity by identifying the source of risk and measure the fraud risk accurately, implementing the proper preventive and detective controls to mitigate those risk, conducting a wide monitoring, and having internal and external auditor that provide performance evaluation.

PT $\mathrm{X}$ is a subsidiary of a public listed company which manufacture floor tiles and wall tiles in Indonesia. In 2018 PT X has been operating in Indonesia for 28 years. PT X has experienced economic and political condition in Indonesia in quite long period. PT $\mathrm{X}$ has already an established governance and business process. However, the mature business process does not reduce the fraud risk in enterprise. The whistleblowing complaint obtained in October 2017 reported that there was a bid rigging transaction of delivery order document by transporter and

\author{
Lufti Julian \\ Departement of Accounting \\ Faculty Economics and Business, Universitas Indoneisa \\ Depok, Indonesia lufti.joelian@gmail.com
}

warehouse, but this complaint remained unsolved because of the absence of evidence and further information from the whistleblower. The complaint referred to delivery process by transporter on domestic sales. Four complaints on August 2017 reported that there were illegal gratuities in loading activity in warehouse. In latest internal audit finding in 2015 , there were found that there was waste in transporter quotation process for IDR412 million. The business process owner could have been economizing for that amount, but there was a tendency to choose certain transporter. There was also an audit finding that the delivery process was performed 1 to 22 days before delivery order was created. Considering all these findings, good delivery process in PT X indicates bid rigging.

The main responsibility of fraud in PT $X$ is still perceived as the responsibility of Internal Audit, instead of management as the ultimate risk owner. Management and employees are still lack of risk awareness. Fraud risks have not been responded in a comprehensive way. Fraud risks in PT $\mathrm{X}$ is still responded by reactive approach that is only performed by Internal Audit. Management of PT X has never applied a fraud risk assessment as initiative step in fraud prevention. Management of PT X has not established the anti-fraud strategy that will eliminate fraud risks. According to the research problem, this study will answer

1. How is the implementation of fraud risk assessment on domestic revenue cycle of PT X to identify fraud risk and scheme?

2. How is the design of anti-fraud strategy that is applicable to PT X to mitigate the fraud risk?

3 . How is the audit program for Internal Audit PT $\mathrm{X}$ to test the effectiveness of control related to identified risk on domestic revenue cycle of PT X?

This study has significance that fraud risk assessment that is performed will enhance the fraud audit approach of PT $\mathrm{X}$ into proactive approach instead of reactive approach. This research applied the fraud risk assessment framework of the Fraud Risk Management Guide COSO 2017 as a method of identifying and responding to fraud before the fraud occurs or proven (preventive measures) instead only 
Internal Audit of PT X that will respond fraud allegation report (detection and deterence). The value of this research is the fraud risk assessment is performed in a public listed company in Indonesia which has wide company's stakeholders, therefore management and internal audit of company might adopt this comprehensive method for fighting fraud in entity.

\section{LITERATURE REVIEW}

According to Cressey [2] the motivation of fraud is explained in a fraud triangle whose elements are opportunity, pressure, and rationalization. Fraud triangle has the fundamental factors in explaining fraud motivation which involves external factor (opportunity) and internal factor from fraudster (pressure and rationalization). Fraud Risk Management Guide COSO [3] applies Fraud Triangle on the framework.

Association Certified Fraud Examiners [4] classified fraud into a fraud tree which consists of three main categories; corruption, assets misappropriation, and financial statement fraudulence. Fraud taxonomy of ACFE has been used widely by professional organizations, such as American Institute of Certified Public Accountancy (AICPA), Institute of Internal Auditors (IIA), and Information Systems Audit and Control Association (ISACA) [5].

Fraud Risk Management Guide [3] provide a systematic guidance for fraud risk assessment with the following steps:

1. Establish the fraud risk assessment.

2. Identify all fraud schemes and fraud risks.

3. Estimate likelihood and significance of each fraud schemes and risk.

4. Determine all personnel and departments potentially involved using Fraud Triangle.

5. Identify existing controls and assess their effectiveness.

6. Assess and respond to residual risks that need to be mitigated.

7. Document the risk assessment.

8. Reassess risk periodically.

Matsura [6] conducts a similar fraud risk assessment on an automotive company in Malaysia and it results that the most frequent fraud is misappropriation of assets and recommendation in fraud prevention. Fahriani [7] conducts fraud risk assessment on small medium enterprise in Indonesia and it results that the most frequent fraud on purchasing cycle is corruption and recommendation in fraud prevention and detection. Karim and Nawawi [8] conducts an assessment of inventory control in a lubricant manufacturing company in Malaysia and it results that problem that leads to fraud and human error may occur due to inconsistency of control practices.

\section{RESEARCH METHOD}

This study uses a qualitative case study approach in data design and data collection. PT X is a unit analysis in this study, including its process business, governance, and documentation. PT X is a subsidiary of a public company engaged in manufacturing floor and wall tiles. Case study approach is applied to comprehend the phenomenon that occur in unit analysis by considering multiple aspects. In data collection the researcher did interview with employee related to revenue cycle, did the surveys, observed the activities of business process owner, and did documentation to PT X sales and employee policies, standard operating procedures, documents on business activities, and internal audit reports. Data primary and secondary were obtained from those research instruments. In data analysis the researcher did content analysis method. After researcher obtained the big picture of company flow process, the researcher went through all the data obtained to formulate the output of study. In data validation, the researcher communicates the finding to Management and Internal Auditor PT X to check the relevance of output and process business.

\section{RESULT}

According to Fraud Risk Management Guide COSO 2017 the researcher performed fraud risk assessment. The first step is to establish fraud risk assessment team which consists of 1.) Sales Administration Supervisor, 2.) Planning Production Control Staff, 3.) Accounting Staff, 4.) Accounts Receivable staff, 5.) Head of Warehouse, 6.) Security, 7.) Internal Auditor, and 8.) Controller Finance Accounting. The fraud risk assessment team consist of individual who comprehend the detail and managerial process. After all the flow process has been captured and all the data obtained from interviews, surveys, observation, and documentation is prepared, the researcher analyzed all the potential fraud risk and schemes in domestic revenue cycle. The second step resulted 26 fraud schemes related to 16 fraud risks on domestic revenue cycle. The third step is to estimate the likelihood and significance of the risks and schemes set by business process owners (see Table 1). The result shows the risk profile that mostly fell on high risk area. The classification of inherent risk profile comprised of four; which only Very Low risk profile that is acceptable to PT X (see Table 2).

The fourth step is to determine all personnel and departments potentially involved using Fraud Triangle. Considering opportunity factors, parties that might involve to fraud schemes are those who relate in a chain process, for instance Sales Admin and customers, Sales Admin and Accounts Receivable Admin, Accounts Receivable Admin and customers, Transporter and Warehouse, and combination of them. Pressure factor can relate to those in the area that potentially give trigger to overstate the work or incentive target. Pressure also refers to those parties that having financial problem and greed therefor the subject can be everyone in company. Rationalization factor refers to employees who is in the lack of supervision. Fraudster believe their act will not be blown up.

The fifth step is to identify existing controls and assess their effectiveness. The adequacy of control is reviewed by control existence that is able to mitigate the impact. 
Control effectiveness is reviewed by relying to Internal Auditor's testing results and self-assessment from process owners. The effectiveness of control is categorized into effective, need minor improvement, need major improvement, and ineffective.

The sixth step is to assess and respond to residual risks that need to be mitigated. The identified risks and schemes that are mitigated by existing control resulted residual risks. The effective existing control move the risk likelihood and significance. The figure 1 shows the profile movement of inherent risk (white dots) into residual risk (black dots).

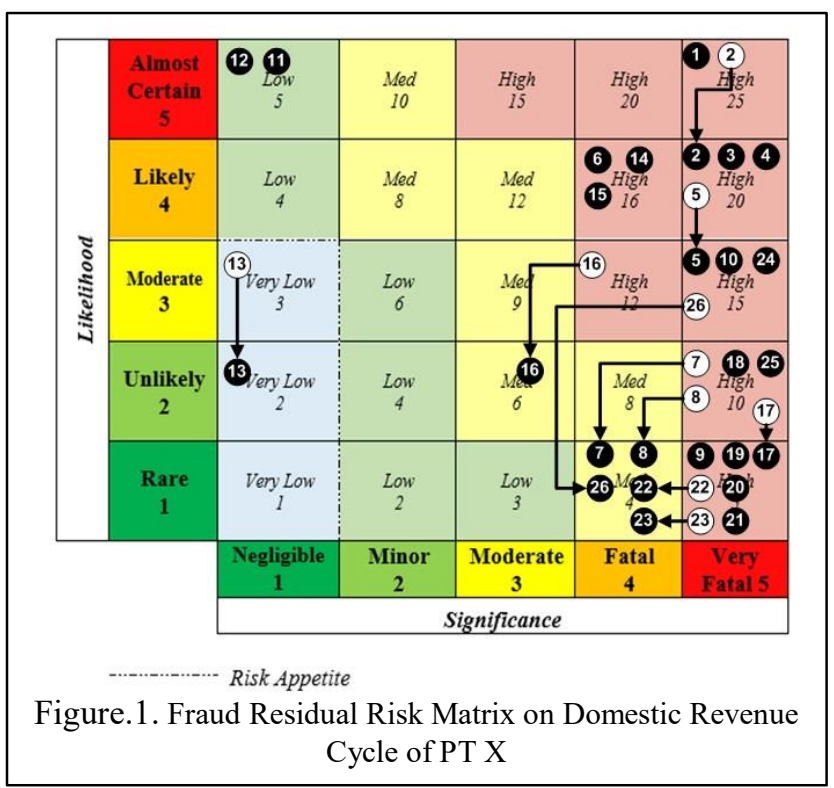

The classification of residual risk profile comprised of four risk profile (see Table 3). The seventh step is to document the risk assessment into a fraud risk register. The eighth step is to reassess risk periodically. This study suggests reassessment frequency should be made according to each residual risk profile (see Table 4).

Considering firm size and governance, the following table shows the design of anti-fraud strategy for PT X. The main program of anti-fraud strategy are prevention program, detection program, and investigation program.

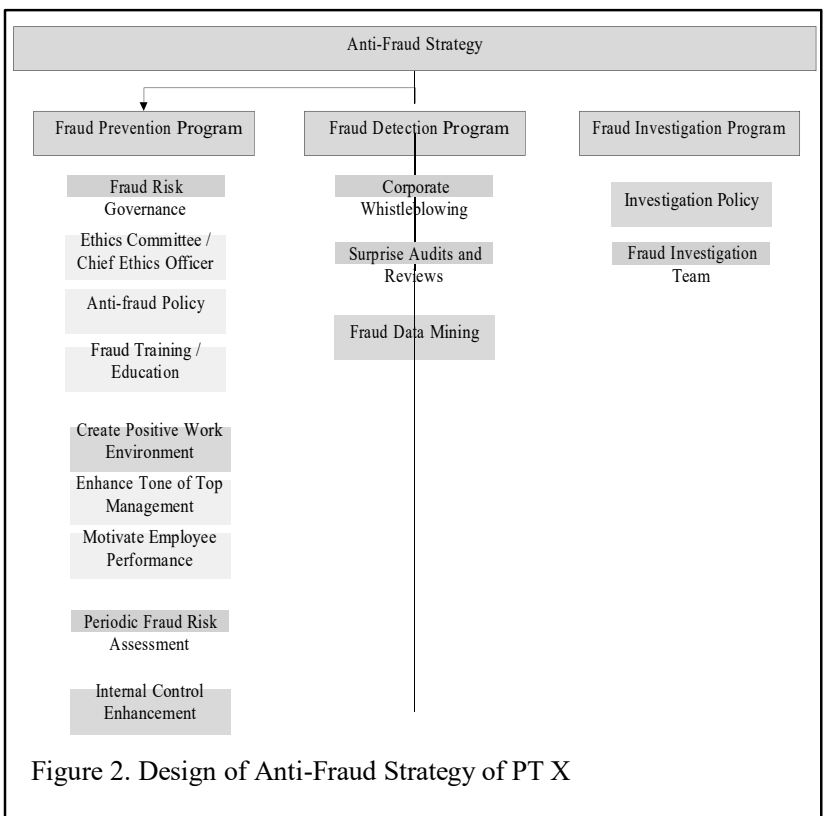

This study also designs program audit that can be used by internal auditor to test control effectiveness related identified control in domestic revenue cycle. Audit program contains audit objects, scope process, related control and risk, frequency audit, audit purpose, and audit procedures.

\section{DISCUSSION}

Fraud risk assessment has identified fourteen fraud risk in domestic revenue cycle in PT X, they are conflict of interest, kickbacks, bill and hold, side agreements, illegal gratuities, bribery, alteration documents, theft of information, insider trading, assets concealment, backdating bill, early recognition, shell company, and fictitious sales. Researcher has identified twenty-seven fraud schemes that may occur related to those risks. Fraud schemes are possible fraud scenario that can be committed by related parties in domestic revenue cycle. The result shows the three main activities that have most risk, they are Sales Administration, Warehouse, and Accounts Receivable Finance. The application of information system has eliminated fraud risks for it reduces manual process. Most inherent risk fell on high risk area. Adequate and effective controls have reduced the level of likelihood. However, residual risks mostly stay in high risk area because the control does not reduce the fatality of impact. Risk respond are to perform by management to mitigate and transfer the risk.

Sales Admin has the main risk to have conflict interest toward customers. Sales Admin should act in favor of the company, which is to maximize the company's profit. However, Sales Admin as the party who interact with customer may act the opposite interest of company, for instance to give more discount to customer, to help customer meet the bonus target in illegal way, and other similar acts. The motivation beyond those acts also should be disclosed and analyzed. There may be illegal agreement amongst Sales Admin to customer, for instance customer gives gratuities or rewards to Sales Admin. Most current controls have been adequate but some controls Warehouse has main risk in inventory (assets) transfer and requisitions. Warehouse employee, security, and transporter are identified to do fraud schemes to conceal the inventory.

Preventive control such as written policy that prohibit employee to commit corruption and bribery is assessed as inadequate to prevent fraud because it has lack of prove that can eliminate the possibility of fraud. Company can only analyze the red flags in operations and need further fraud penetration. After the good issued from warehouse, company fully relies to Transporter and there is high risk on it. Risk related to third party, may be responded by risk transfer that Transporter should bear the loss because of the infringement made by them. Delivery Order that should be stamped by Customers as they received the goods is an effective control for it give legitimation and confirmation that the delivery process has been performed well.

Accounts Receivable has the main risk related to invoicing process that is still performed manually. The high-risk activities are calculation credit note and processing date of invoice. AR Admin is identified that 
potentially able to give over calculation of credit note that may reduce the amount of sales because of conflict interest. This goes same with Sales Admin; this conflict of interest may be triggered by illegal agreement among AR Admin and Customer. The control of this risk is review and supervision from AR Supervisor. Management assessed that this control has been adequate and effective.

There are some financial statement fraudulences that might occurs in PT $X$, they are early recognition, backdating bill, sales side agreement, fictitious sales, and shell company. Some controls have been adequate to mitigate the risk of improper recognition. However, risk of financial statement that is initiated by management is nearly impossible to mitigate with control set in flow process, for instance company creates fictitious sales to boost up accounts receivable. If the management instruct employees to do so, none will explicitly use control to hinder this conflict, therefor external auditor is viewed as detective control of this risk.

This study design anti-fraud strategy to PT X which mainly consist of preventive program, detection program, and investigative program. Responding to risk fraud in PT $\mathrm{X}$ has been initiated by Internal Audit PT X. However, the ultimate risk owner is management, not internal auditor, therefor management should be the one who design the fraud risk response. With the anti-fraud strategy, management will have guidance to initiate fraud risk governance and enhance the current program. This study also designs audit program to test effectiveness of current control. The audit program is designed according audit scope in identified risk, they are Sales Order process, credit note calculation, credit limit, goods loading, delivery process, and invoicing. The purpose of the program audit is to check the result whether the existing control has been operating effectively. The auditor or assessor may see the audit finding pattern in certain span of time. To further investigation, company can perform fraud penetration program.

\section{CONCLUSION}

Fraud risk assessment has identified Sales Administration, Warehouse, and Account Receivable are the riskiest area in domestic revenue cycle of PT X. Fourteen fraud risks in domestic revenue cycle in PT X are identified; conflict of interest, kickbacks, bill and hold, side agreements, illegal gratuities, bribery, alteration documents, theft of information, insider trading, assets concealment, backdating bill, early recognition, shell company, and fictitious sales. Management and employee of PT X have not noticed that they are the ultimate risk owner. The long operational period does not prescribe risk-awareness maturity. Fraud risk assessment is still a new method for company to identify risk. Fraud risk assessment always need to be refined and reassessed overtime.
Audit program is designed to test effectiveness of current control. The audit program is designed according audit scope in fraud risk assessment which control is adequate. The scopes are Sales Order process, credit note calculation, credit limit, goods loading, delivery process, and invoicing. Audit program helps auditors to determine area that need to be reviewed, frequency of audit, and steps that need to be taken. Audit program also helps auditors to document the audit process. Audit program need to be updated along the fraud risk assessment.

\section{RECOMMENDATION}

Researcher recommends to PT X to enhance the fraud risk awareness that fraud risk can be identified, managed, and mitigated and to enhance awareness that management is the ultimate risk owner, to implement anti-fraud strategy and initially to create fraud policy, ethics committee or chief ethic officer that will be responsible of fraud risk governance and activities, to implement fraudrisk respond related to the identified risks and schemes, and to periodically perform fraud risk assessment and to apply fraud risk assessment on other business cycle.

Researcher recommends to Internal Auditor PT X to do consulting role to management to educate risk concept, fraud, and internal control to employee, to use fraud data mining software to enhance efficiency the fraud detection activity, and to perform control testing and document it as regular monitoring activity.

\section{REFERENCES}

[1] Albrecht, W. Steve, Albrecht, Chad O., Albrecht, Conan C., Zimbelman, Mark F. (2012). Fraud Examination. Fourth edition. Ohio; South-Western Cengage Learning.

[2] Cressey, Donald. R. (1973). Other people's money; a study of the social psychology of embezzlement. International Review of Modern Sociology, Vol. 3, No. 1 (March, 1973), pp. 114-116. https://www.jstor.org/stable/pdf/41420485.pdf accessed on 15 March 2018 05:58 pm.

[3] Fraud Risk Management Guide. Committee of Sponsoring Organizations of the Treadway Commission. (2017).

[4] Association of Certified Fraud Examiners. (2016). Report to The Nations on Occupational Fraud and Abuse. https://www.acfe.com/rttn2016/docs/2016-report-to-the-nations.pdf accessed on 27 November 2017 11:23 pm.

[5] Tjahjono, Subagio, et al. (2013). Business Crimes and Ethics. Yogyakarta; Andi.

[6] Mastura Omar, Anuar Nawawi, Ahmad Saiful Azlin Puteh Salin, (2016). The causes, impact and prevention of employee fraud: A case study of an automotive company. Journal of Financial Crime Vol. 23 Issue: 4, pp.1012-1027, https://doi.org/10.1108/JFC-042015-0020

[7] Fahriani, Mega S. (2017). Penerapan Fraud Risk Assessment untuk Mengantisipasi Kecurangan pada Siklus Pembelian Barang (Studi Kasus Pada Usaha Kecil dan Menengah: PT X). Salemba; Univeristas Indonesia.

[8] Norazira Abd Karim, Anuar Nawawi, Ahmad Saiful Azlin Puteh Salin. (2018). Inventory control weaknesses - a case study of lubricant manufacturing company. Journal of Financial Crime, Vol. 25 Issue: 2, pp.436-449. https://doi.org/10.1108/JFC-11-2016-0077 
TABle 1 LiKelihood Fraud of Domestic ReVEnue CyctLe of PT X

\begin{tabular}{|c|c|c|}
\hline Score & Frequency & Description \\
\hline 1 & Rare & Once in a year \\
\hline 2 & Unlikely & Once in nine months \\
\hline 3 & Moderate & Once in six months \\
\hline 4 & Likely & Once in two to three months \\
\hline 5 & Almost Certain & Once in a month \\
\hline
\end{tabular}

Table 2 Significance Fraud of Domestic Revenue Cyctle of PT X

\begin{tabular}{|c|c|c|c|}
\hline \multirow{2}{*}{ Score } & \multirow{2}{*}{ Category } & \multicolumn{2}{|r|}{ Description } \\
\hline & & Financial Impact & Non-financial impact \\
\hline 1 & Negligible & IDR 0 & $\begin{array}{l}\text { 1. Infringement is considered very light by the company; } \\
\text { 2. Employee shows undisciplined and impolite acts. } \\
\text { 3. The infringement does not affect to work situation and company operation. } \\
\text { 4. The sanction is in the form of oral reprimands or Warning Letter } 1 \text {. }\end{array}$ \\
\hline 2 & Minor & $\begin{array}{c}\text { IDR } \\
0-500.000\end{array}$ & $\begin{array}{l}\text { 1. Infringement is considered light by the company; } \\
\text { 2. Employee keeps showing undisciplined and impolite acts after given reprimands and } \\
\text { warning letter } 1 \text {. } \\
\text { 3. Employee uses company assets or facility to personal benefit. } \\
\text { 4. Employee tolerate the own safety in working. } \\
\text { 5. The infringement does not affect to work situation and company operation. } \\
\text { 6. The sanction is in the form of oral reprimands or Warning Letter } 2 \text {. }\end{array}$ \\
\hline 3 & Moderate & $\begin{array}{c}\text { IDR } \\
500.000-1.000 .000\end{array}$ & $\begin{array}{l}\text { 1. Infringement is considered as moderately serious by company; } \\
\text { - Employee keeps showing undisciplined and impolite acts after given reprimands } \\
\text { - } \quad \text { Emd Warning Letter } 2 \text {. } \\
\text { - Employee uses or impairs company assets or facility to personal benefit. } \\
\text { - Employee intervenes other employee work without the order of his/her superiors. } \\
\text { 2. The infringements do not affect to company operation but it does affects negatively to } \\
\text { work situation. } \\
\text { 3. The sanction is in the form of Warning Letter } 3 \text {. }\end{array}$ \\
\hline 4 & Fatal & $\begin{array}{c}\text { IDR } \\
1.000 .000-5.000 .000\end{array}$ & $\begin{array}{l}\text { 1. Infringement is considered as serious by company; } \\
\text { - Employee keeps showing undisciplined and impolite acts after given reprimands } \\
\text { and Warning Letter 3. } \\
\text { - Employee uses or impairs company valuable assets or facility to personal benefit. } \\
\text { - Employee does the opposite of his/her job description. } \\
\text { - } \quad \text { Those infringement acts will make company suffer loss. } \\
\text { 1. The infringement does affect to company operation and it does negatively affect to work } \\
\text { situation. } \\
\text { 2. The sanction is in the form of suspension. }\end{array}$ \\
\hline 5 & Very Fatal & > IDR 5.000 .000 & $\begin{array}{l}\text { 1. Infringement is considered as very serious by company; } \\
\text { - } \quad \text { Employee commits or causes or helps people to commit fraudulence, theft, } \\
\text { - } \quad \text { Employee accepts rewards from any parties relates to his/her job or position in } \\
\text { company. } \\
\text { - Employee testifies or gives false information to company or state. } \\
\text { - } \quad \text { Employee commits immoral act. } \\
\text { - } \quad \text { Employee threatens or does physical intimidation to company's business partner, } \\
\text { - Employee influence coworker to do unlawful acts. } \\
\text { - } \quad \text { Emped by company. } \\
\text { - Employee disgraces company image before public. } \\
\text { - } \quad \text { Employe or impairs highly valuable company assets or facilities that causes } \\
\text { - Employee does any illegal charges in work environment. } \\
\text { - } \quad \text { Employee spreads written provocation that contains mockery to management. } \\
\text { The infringement negatively affects to company operation and it negatively affects to } \\
\text { work situation. } \\
\text { 3. The infringement can be subject to criminal laws with } 5 \text { years penalty. } \\
\text { 4. The infringement causes or potentially causes lawsuits or labor demands for company. } \\
\text { 5. The sanction is in the form of work termination with or without severance compensation. }\end{array}$ \\
\hline
\end{tabular}


Table 3 Description of Inherent Fraud Risk Profile of Domestic Revenue Cycle of PT X

\begin{tabular}{|c|c|c|}
\hline Risk Profile & Acceptability & Description \\
\hline Very Low & Acceptable risk & $\begin{array}{l}\text { - Company accept the risk } \\
\text { - Immaterial loss and does not affect operational business. } \\
\text { - Company does not give any concern at this risk } \\
\text { - Company requires extreme effort to mitigate these risks. }\end{array}$ \\
\hline Low & & $\begin{array}{l}\text { - Company does not accept the risk } \\
\text { - Company does risk respond; risk mitigation, risk transfer, and risk avoidance. } \\
\text { - The loss might be material for company but it does not affect operational business. } \\
\text { - Company has no urgency in mitigate these risks } \\
\text { - Company requires great of effort to mitigate these risks. }\end{array}$ \\
\hline Medium & Unacceptable risk & $\begin{array}{l}\text { - Company does not accept the risk } \\
\text { - Company does risk respond; risk mitigation, risk transfer, and risk avoidance. } \\
\text { - The loss is material for company and might be affecting the operational business. } \\
\text { - There is urgency for company to mitigate these risks. } \\
\text { - Company requires quite great of effort to mitigate these risks. }\end{array}$ \\
\hline High & & $\begin{array}{l}\text { - Company does not accept the risk } \\
\text { - Company does risk respond; risk mitigation, risk transfer, and risk avoidance. } \\
\text { - The loss is very material for company and affects the operational business in various scale. } \\
\text { - The risks become main concern of company and there is urgency to respond these risks. } \\
\text { - Company does not require great effort to mitigate these risks. }\end{array}$ \\
\hline
\end{tabular}

Table 4 Description of Residual Fraud Risk Profile of Domestic ReVenue CyCle of PT X

\begin{tabular}{|c|c|}
\hline Risk Profile & Description \\
\hline Very Low & The risk is accepted by management therefore the risk does not become management's concern. \\
\hline Low & The risk still can be accepted by management and there is no urgency to respond this risk. \\
\hline Medium & The risk cannot be accepted by management and there is urgency to respond this risk. \\
\hline High & The risk cannot be accepted by management and there is huge urgency to respond this risk. \\
\hline
\end{tabular}

TABLE 5 REASSESSMENT FREQUENCY

\begin{tabular}{|c|c|}
\hline Residual Risk Profile & Frequency of Reassessment \\
\hline Very Low & Not required \\
\hline Low & Once in more than 2 years \\
\hline Medium & Once in 1 to 2 years \\
\hline High & Once in more than 1 year \\
\hline
\end{tabular}

